\title{
Environmental Direct Action in Manchester, Oxford and North Wales: A Protest Event Analysis
}

\author{
Brian Doherty, Alexandra Plows and Derek Wall ${ }^{1}$
}

This is an electronic version of an article published in Environmental Politics

Volume 16, Issue 5, 2007, pp.805-825

(Special Issue: Acting Locally: Local Environmental Mobilisations and

Campaigns.) It is available online at:

http://www.tandfonline.com/doi/abs/10.1080/09644010701634182

\begin{abstract}
Direct action campaigns against new roads in the UK received much attention, but campaign groups were locally organised and little is known about how they worked. Protests by three local environmental direct action groups in the years 1992-2001 are examined. Their repertoire was confrontational, targeted mainly at business and the state. Most protests were small-scale and most were unreported in either local or national media. In the larger groups, in Manchester and Oxford, most actions were carried out locally and direct action groups worked mainly alone. In the smaller Bangor group, campaigners sometimes needed alliances with less radical groups to campaign effectively, and travelled more to events outside their locality. Environmental direct action groups remain largely autonomous from strategic alliances, locally or nationally, and from efforts to influence state policy. Their protests are challenges to the norms underlying political and capitalist institutions rather than calculated attempts to influence government. Evidence that their actions, on issues such as road-building, genetic modification, global justice and climate change, were affecting public debate sustained and revitalised action more than did changes in political opportunities.
\end{abstract}

\section{The Environmental Direct Action Movement ${ }^{2}$}

A network of environmental direct action groups first emerged in the UK at the beginning of the 1990s, in protest against road building, the importation of tropical hardwoods and the colonisation of public space by motor vehicles. This was in marked contrast to what had seemed to be a domesticated UK environmental movement, focused on lobbying (Doherty 1999a, Rootes 2000, Wall 1999). In part, their emergence was a reaction against the limited opportunities for participation offered by mainstream environmental movement organisations such as Greenpeace and Friends of the Earth. Most activists in the new environmental direct action (EDA) groups were young, middle class, university educated, and new to political activism (Wall 1999). Although the local groups adopted their own names, the network was loosely linked at the national level as 'Earth First!' from 1992 onwards and national Earth First! 'gatherings' provided local EDA groups with opportunities to discuss strategy and common perspectives (Seel and Plows 2000).

Earth First! began in the USA in 1980 as a network of activists prepared to use sabotage to defend wilderness areas against development (Lee 1995). Other wilderness defence groups using direct action had also existed in Australia from the late 1970s (Doyle 1994). While the British groups that emerged in the 1990s took 
tactics and inspiration from their New World counterparts, with little wilderness to defend they focused on other, often urban, targets. They were also less biocentric in their philosophy and were more influenced by British traditions of non-violent direct action that had preceded the turn to environmental issues in the 1990s.

Although environmental direct action groups in the UK gained much attention during the 1990s, little is known about their actions away from the high profile campaigns against new roads and GM crops, or whether the nature of their protest varied significantly by locality. Our investigation, carried out between 2000 and 2002, is of British EDA groups in Bangor (North Wales), Manchester and Oxford. We use the term environmental direct action (EDA) groups because this was a term that activists used themselves and signifies the emphasis given within these groups to direct action forms of protest. The use of group does not signify that they had formal organisations. There were no office holders in any of these groups. Also, while most Manchester and Bangor activists organised under the Earth First! banner, in Oxford there was sometimes a group called Earth First! and at other times unnamed and ad hoc collections of the same EDA activists.

These locations were selected because of their different environments, and their different roles in the EDA network. Manchester is at the centre of a major conurbation of over 2 million people with high levels of poverty; Oxford is a more affluent small city of 140,000 people, in southern England and Bangor is a small town of 14,000 people in mainly rural North-West Wales, where levels of income are below the UK average. Oxford and Manchester EDA groups played important roles in co-ordinating national EDA campaigns during the 1990s and, along with Brighton, Bristol, Cardiff, Leeds, London, Newcastle, Norwich and Nottingham, were regarded as among the strongest activist communities. North Wales was among a second group of locations in which there was fairly consistent activity by a smaller group of activists. ${ }^{3} \mathrm{We}$ defined activists as those who attended Earth First! or equivalent EDA group meetings and regularly took part in direct action protests.

In Manchester this was between 25 and 40 people. The largest EDA actions in Manchester, such as the May Day protests in 2000, mobilized up to 500 participants, but most of them did not attend Earth First! meetings regularly and so were not classified by us as EDA activists. Most activists lived in 'hard to let' apartments owned by the city council in a few streets in Hulme, close to Manchester city centre, within a countercultural scene of alternative arts and politics, a smaller scale version of the alternative scenes in Kreuzberg, Berlin and other German cities in the 1980s and 1990s (Haunss and Leach 2004).

Oxford had a smaller number of core EDA activists, usually around 20, but as in Manchester a wider green community of several hundred would support major EDA protests such as the Halloween Reclaim the Streets party in 1998. In periods when there was no Earth First! group in Oxford, other EDA projects filled the gap. Corporate Watch was an independent research group that carried out research on corporations least beloved of environmental and other social movement groups. Its suite of offices in East Oxford was shared with other office projects such as Undercurrents, a radical newsvideo production group, and was the base for much of Oxford's EDA networking. 
Gwynedd and Mon Earth First! (GMEF) based in Bangor, North Wales was a much smaller group with usually fewer than 10 regular activists. The Bangor area had seen a countercultural influx in the 1970s but there were few ties with local Welsh nationalists who had their own traditions of direct action in defence of Welsh language and culture. The establishment of a new resource centre with offices for campaign groups in the early 1980s and a shared commitment to peace movement and anti-nuclear campaigns led to stronger ties between Welsh speakers and mainly English incomers. The young Earth Firsters!, several of whom were students at Bangor University in the early 1990s, did not have close links with either group initially. However, an Earth First! campaign against a new housing project on greenfield land after 1994, led to new alliances. By the end of the decade, the Earth First! group in Bangor had stronger links with other local campaigners than the larger EDA groups in Manchester and Oxford.

The three areas we studied all had legacies from the left-wing counterculture of the 1970s and 1980s: alternative projects of various kinds, such as cafes, radical bookshops, campaign offices and resource centres that served as meeting places. There was also a history of earlier direct action on anti-military, anti-nuclear, antifascist, housing and community issues. All three had strong local peace groups in the 1980s, including women's groups supportive of the Greenham Common Women's Peace camp. Activists from these 70 s and 80 s groups were still present in a variety of local campaigns that brought them into contact with the new environmental activists of the 1990s. ${ }^{4}$

The constellation of local politics was less significant. Differences in the political characters of the local authority in each area had no discernable impact on the nature of local EDA protest. Manchester City Council was Labour-dominated but while older activists talked of the Labour Party in the 1980s as having been responsive to their concerns, by the 1990s the party in Manchester, like Labour nationally, was moving away from support for social movement agendas and favoured development schemes such as the expansion of the airport that were opposed by local greens. The Labour-led Council therefore became a target of regular protests. In Bangor, Plaid Cymru, the Welsh nationalist party, led the local council. Although Plaid had a record of support for environmentalism, its local support for development projects led EDA activists to see it as mostly part of the opposition. In Oxford, the strongest local Green Party in the UK controlled the City Council for a time as the minority party in coalition with the Liberal Democrats, but rather than this averting protest in Oxford, Green councillors on several occasions joined in protests organised by local EDA activists.

The failure of patterns of local politics to differentiate among our cases is explained by the lack of power of local authorities, which reduced their salience, and EDA activists' lack of interest in negotiable policy impact. EDA activists saw their role as raising issues through protest or increasing the political or financial costs of their opponents; influencing policy through negotiations even at local level was not part of this strategy. 


\section{Measuring Direct Action Protest: Methodological Challenges}

Analyses based upon newspaper reports have become the principal means of measuring protest (Rucht 1992) but it is also clear that newspapers have limitations as sources (Fillieule and Jiménez 2003). Novel and colourful or violent protests may often receive coverage when larger protests are ignored, particularly if the larger march or rally seems merely to repeat the formula of previous events on an issue that is already assumed to be familiar to readers (Downs 1972). While the issue attention cycle may have favoured the reporting of direct action protests in the early 1990s in the UK, what had once been novel forms of protest received diminishing coverage in later years. ${ }^{5}$

Rather than showing the scale and frequency of protests, reports in national newspapers can be argued to record the visibility of protest (Rootes 2003). This in itself may be an indicator of a movement's political impact, but we cannot be sure that the protest activity of movements has declined simply because their actions are not covered by the newspapers. Furthermore it is not necessarily the case that newspapers are always the best source of data for protest event surveys. Even when interest in environmental direct action was at its height coverage in The Guardian, the national newspaper most attentive to environmental action, was not comprehensive. The Guardian reported 128 environmental protests by Earth First! or other EDA groups between 1992 and 1997 (Rootes 2003). ${ }^{6}$ By comparison, EDA national newsletters reported 684 separate protests involving EDA groups in the same period. Even allowing that some of the non-environmental protests by EDA groups would have been excluded from the environmental protests covered in The Guardian, this is a significant difference.

The culture of EDA groups compounds the problems associated with relying on press sources to measure their protest. There was a widespread hostility in EDA networks to the media, which was seen as incapable of reporting their actions accurately. Activists felt there was too much interest in their lifestyle and too little in the reasons for their protest and so they often avoided contact with reporters. EDA groups thus stand outside the general assumption that good mass media coverage is seen as essential by contemporary social movements. When good media coverage happened it was welcomed, but for the most part EDA activists neither sought nor expected it. The alternative, which they pursued with some vigour in the 1990s, was to offset their lack of coverage in mainstream media by creating their own media. In doing so, they were following a long established trend among radical groups but unlike most of the earlier radical press, Earth First! Action Update (EFAU), the most consistent newsletter in the EDA network had no editorial discussion, letters or by-lines. EFAU was a monthly, free, four-page newssheet, distributed on paper or by email. It simply reported events and carried event listings and contact details for the 25-40 EDA groups, plus an occasional insert with a practical briefing on issues such as legal rights when arrested. Production of EFAU rotated among local EDA groups annually; Oxford and Manchester (twice) edited it during the period we surveyed. A Brighton direct action collective also produced Schnews, a weekly national newssheet, distributed on paper, by email and on the web. Schnews carried analysis but also reported protest events, although less comprehensively than EFAU. EDA groups in Manchester and Oxford also produced local free newsletters: Loombreaker (Manchester) and Oxyacetelene (Oxford) reported local protests and publicised upcoming events, and paper copies were distributed in activist haunts. These local 
EDA sources often covered events that were not reported on in the national EDA newsletters.

The results reported here are based on a survey of EFAU and Schnews, local newsletters in Manchester and Oxford and, in the absence of a local newsletter in the case of North Wales, participant observation by one of the researchers covering the years 1995-2001. We do not claim that activist media are always and necessarily superior to newspapers, or that they escape problems of selectivity, only that for the subject we studied they were the most comprehensive and reliable sources available. We were fortunate in that the kind of newsletters favoured by EDA groups in the 1990s were particularly appropriate and maintained sufficient continuity for protest event analysis. ${ }^{7}$

\section{Incidence of EDA Protest Nationally}

To assess the national picture we counted all protests (environmental and nonenvironmental) by UK EDA groups reported in EFAU and Schnews ${ }^{8}$ over the ten years from 1992 to the end of 2001 (see Figure 1).

\section{Figure 1. EDA Protest Events in the UK 1992-2001, reported in Earth First! Action Update and Schnews.}

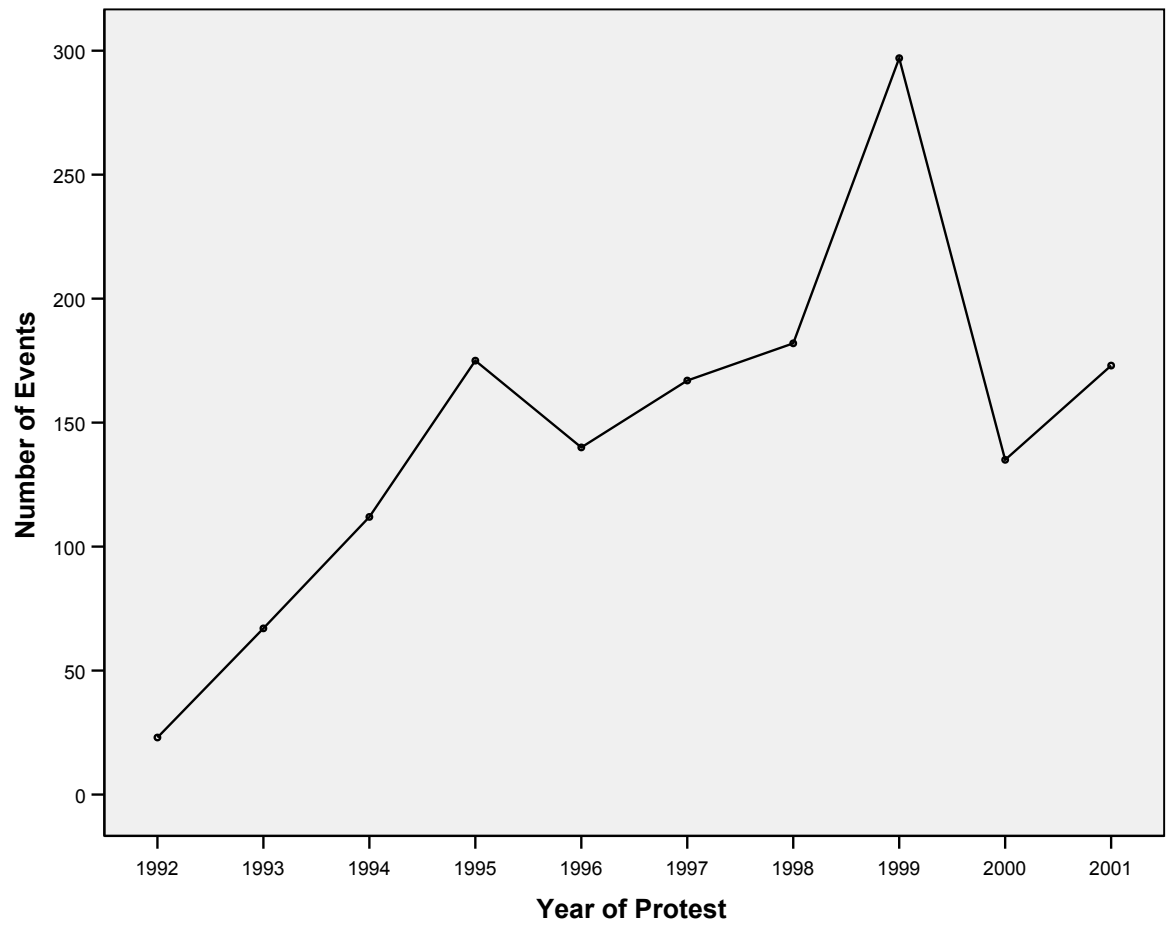

1999 represents the peak when 297 separate protest events ${ }^{9}$ took place, out of a total of 1471 in the ten years surveyed. However, the number of protests may not be equivalent to the level of protest activity. The rise in the number of events in 1998 and 
1999 was connected to the decline in protest camps by the end of 1997. Protest camps generate few separate events, ${ }^{10}$ but since they usually last for several months and sometimes more than a year, they are a particularly intensive form of action. They were particularly numerous during the anti-roads campaigns between 1994 and 1997 when the proposed routes of new roads were occupied in order to obstruct construction.

There was considerable activity in 1998 and 1999 because the movement was mobilising on new issues such as global justice, which led to protests at the G8 Summit in Birmingham in 1998, followed in June 1999 by the Carnival Against Capitalism in London which coincided with the G8 Summit in Cologne. Other new targets for protest in these years were the farm trial sites for genetically modified crops, which became the focus of a sabotage campaign. The decline in events in 2000 is sufficiently marked to suggest that fewer actions were occurring. While there was some stabilisation in 2001, activists we interviewed said that the number of actions was declining in the new millennium. This was confirmed by the petering out of local newsletters and the Earth First! Action Update around this time. EDA did not end in 2001. Earth First! gatherings continued as did direct action, but it was undoubtedly on a smaller scale than in the 1990s.

\section{The Incidence of Local EDA Protest}

We turn now to examine the evidence on local protest. Local EDA newsletters often reported events missing from national activist sources. Sometimes these were protests in which local EDA groups worked in coalition with residents or other less radical groups, which might have seemed less interesting to other EDA groups. One example was a site occupation, reported only in Oxyacetelyne (November 1998), to protest at the felling of chestnut trees so that a road could be built in Oxford. Because local newsletters, and participant observation only covered the period 1995-2000, we were only able to examine 6 of the 10 years for which we also had national sources. Figure 2 includes all protest reported in one or more of the national and/or the local sources that took place in our three areas during those six years.

Figure 2. EDA protests in Manchester, Oxford and North Wales 1995-2000, reported in national and local sources. 


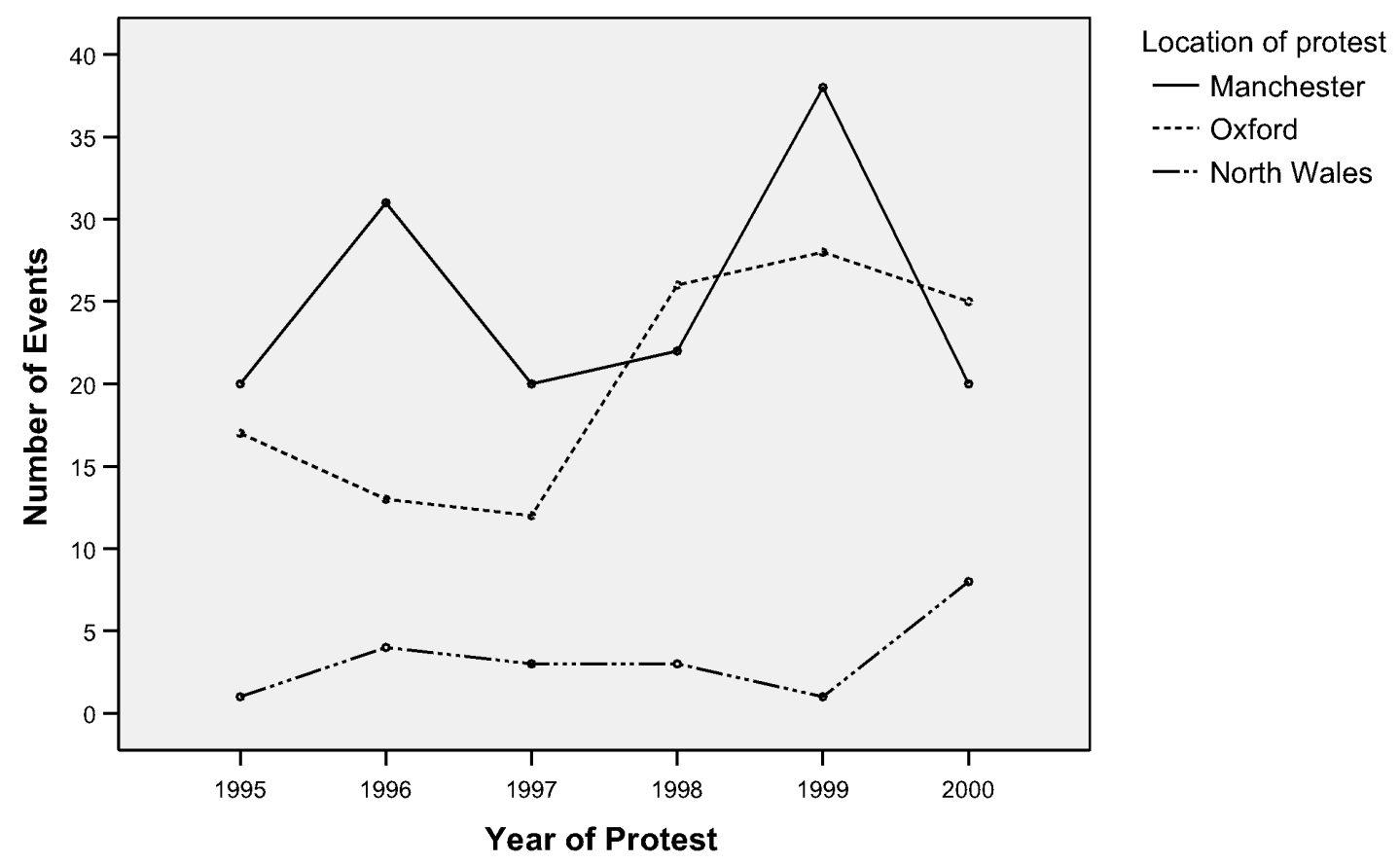

It is notable that local patterns of action do not correspond neatly to the national patterns. Local factors clearly influence the level of activity that EDA groups are able to sustain The first notable peak of activity in Manchester in 1996 was due to local campaigns against urban pollution by an EDA-led group, Fresh Air Now, and protests against the construction of a new orbital motorway in the east of the city. The decline in events in 1997 and 1998 reflects the effect of the anti-airport protest camp in the first half of 1997, which, despite increasing the intensity of activity in Manchester, reduced the number of reported events. Around 150 activists were evicted from treehouses and tunnels on the site of the planned second runway over three weeks in April and May 1997. Thereafter, activists were, according to one interviewee, 'burned out'. A second factor was the withdrawal from confrontation of several key activists in 1997, in order to establish a new environmental resources centre with charitable and public funds. Further protest camps at the airport site in 1998 and 1999 were much smaller and had little active support from most EDA activists in Manchester.

In Oxford, the lower levels of action in 1995 and 1996, compared with the previous year and also with Manchester, reflected the role of Oxford activists in the Newbury bypass campaign in 1995-6. Oxford is close to Newbury and activists from the city were more heavily involved with the campaign than those from Manchester or North Wales. Many mentioned Newbury as a turning point, following which many of those involved since the early 1990s felt exhausted and either retired or took a break from activism. The dramatic peak of activity in Oxford in 1998 was due to the emergence of local 'issue opportunities' - specific instances that facilitate mobilization for groups already predisposed to act on that issue - including the demolition of a prized old cinema, which was squatted by EDA activists and used as an alternative arts venue for a time. ${ }^{11}$

The smaller group in North Wales carried out fewer local protests. The pattern of action is similar to Oxford up to 1998, when GMEF established a protest camp 
against a new housing project in Bangor. Following the partial success of the campaign, which reduced the number of houses to be built, activists were too tired to relaunch actions until later in 1999. In 2000 GMEF initiated a new direct action network that improved links between Welsh groups and stimulated new activity..

Travelling to protest: comparing local and extra-local protest activity Analysis of local sources allows for more accurate identification of the involvement of groups from Manchester, Oxford and North Wales in events outside their areas. Figure 3 shows protests that took place in Manchester, Oxford and North Wales and also protests in other places where activists from the three local groups were reported to be involved. This is the most comprehensive record that we have of the protest activity of these groups covering the six years 1995-2000 and it allows us to compare the balance of local and extra-local activity of each group. Figure 3 shows 1996 to be the peak year of activity when activists from all three areas went to join the protest camps at Newbury regularly. ${ }^{12}$ Nevertheless there was also considerable local protest action in 1996 in addition to this (see Figure 2). The combination of significant local and protest camp action is consistent with the accounts given by activists in interviews, for whom 1996 was the highpoint of EDA action. ${ }^{13}$ It is worth noting that the larger groups in Manchester and Oxford carried out more local protests than protests outside their area, whereas the North Wales activists took part in more events that involved travelling than local actions.

Figure 3. EDA protests in all locations by activists from Manchester, Oxford and North Wales 1995-2000, reported in national and local sources.

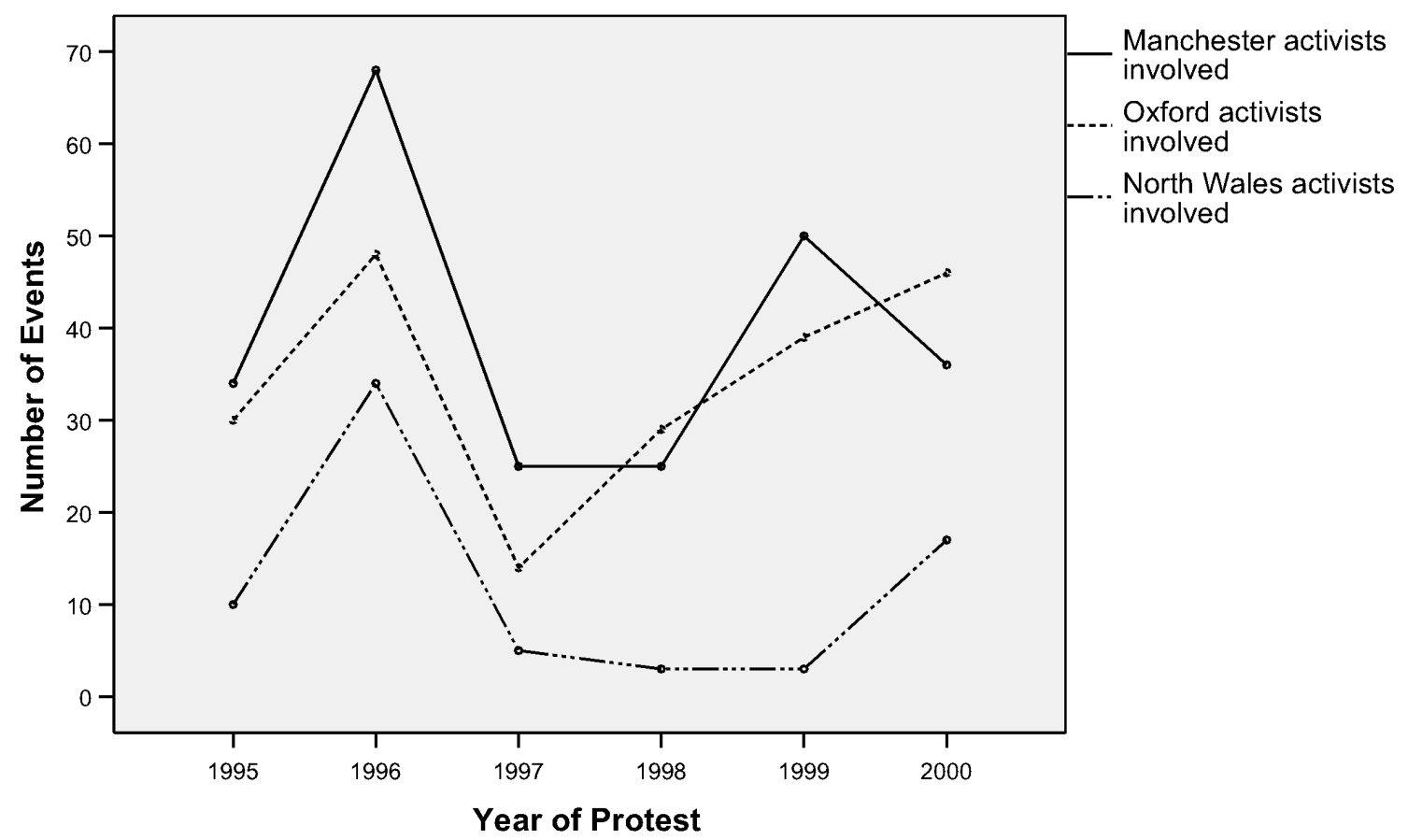

In the patterns of action reported in Figure 3 there is evidence for a cyclical effect similar to that which McAdam (1983) identified in the US civil rights movement during the years when protest was at its height: in that case, moments of tactical innovation, such as the sit-ins at lunch counters in the Spring of 1960, produced an increase in all forms of protest action by the civil rights movement. There were 
tactical innovations by UK EDA groups such as the creation of tunnels to extend site occupations (first used successfully at Fairmile in Devon in 1997, Doherty 1999b), but in the three areas that we studied increased protest was most evident in periods when the movement was at the top of the news agenda rather than following moments of tactical innovation. Notwithstanding EDA activists' ambivalence about the media, it seems likely that being covered on the nightly news, as the movement often was in the months leading up to and in the course of the Newbury evictions in 1996 and at certain moments in 1999-2000 (anti-GMO protests in 1999-2000; the June $18^{\text {th }}$ Carnival Against Capitalism in London; by proxy in the case of their allies at the Seattle protests in November 1999; the May 2000 London Guerrilla Gardening action in London and the Prague protests of September 2000), encouraged all those involved to believe that their action was having an effect. It may also have encouraged an increase in reporting of events by activists in the national EDA newsletters. If so, this would be consistent with the pattern noted in reports of environmental protests in The Guardian (Rootes 2003). Nevertheless, in the case of EDA groups the effects of such major reinforcing events have to be weighed against the after-effects of waging a big campaign locally, which often led to 'burnout'.

Burnout can also explain some of the ups and downs evident in Figure 3. While there was an increase in local action in Oxford in 1998, this was less evident in Manchester and North Wales. In Manchester activists were tired after the eviction of the protest camps at Manchester Airport, which took place over several weeks in April and May 1997, and the same pattern followed in North Wales in 1999 after the eviction of the protest camp against new housing in 1998. While action picked up again in 1999 in Manchester, and 2000 in North Wales, there was a decline in Manchester in 2000 after another very active year in 1999.

Personal relationships, recruitment and local activist community cycles As well as the effects of local cycles and national campaigns, the movement of a few key individuals in or out of a local activist community also affects the level of activity. At the micro-level, events such as the end of a relationship between two activists, or personality clashes can have a significant effect on the whole group.

These things are cyclical and the Oxford scene went into decline for various reasons, partly it was personality clashes actually. I remember it being very optimistic when it started 'we don't do ego', ... 'this is just for the cause', ... this kind of stuff. And you actually genuinely believed this for quite a while and then people's egos start to take over, and people start having massive disagreements, and there was a big split within Corporate Watch, which really fucked things up quite badly and never really recovered. Also people went off in different directions; some people went off doing national campaigns, people went to squatting stuff, some people went to be artists, people got interested in other things. (Interview with 'Luke' ${ }^{14}$ Oxford, 2000)

After the first few years of activism in the 1990s relatively little effort was made to recruit new activists into EDA groups. This is a common pattern for direct action groups since they are usually small groups linked by strong bonds of trust, shared experience and friendship. While there are no formal barriers to new members, anyone joining would find it hard to break into such friendship networks, a point made by several interviewees (cf. Polletta, 2002, on these processes in US social movements, and La Rocca (2004) on Australian environmental activists). As a result, 
in contrast to movements with more impersonal forms of organization, the numbers involved in EDA did not expand greatly in the UK even when its protests appeared to be having some political impact. The hidden structure of small groups of friends within local EDA networks also helps to explain some of the cyclical patterns of action locally. When activists retired or the group was 'burned out' it was not possible to increase the level of activism because there were no new activists to take up the challenge. On the other hand, even if it is in certain senses closed to outsiders, sustained direct action is a very durable form of mobilisation and many activists remained involved for more than five years. Strong ties forged over years of demanding activism still bound previous generations of activists in these localities from the 1970s and 1980s to their activist-friends and continued EDA protests in the mid-2000s suggest it is likely that this will remain the case for those from the 1990s. But this hidden structure also acts as an obstacle to the transmission of mobilisation over time because the next generation have to make their own networks anew.

\section{The Issues of Protest}

One measure of the localness of EDA groups is their ability to respond to issues that are distinctly local in scope. Figure 4 shows the balance between protests that were classified as either local, national or international. ${ }^{15}$

Figure 4. Scope of Issue at Stake (all 3 areas combined 1992-2001).

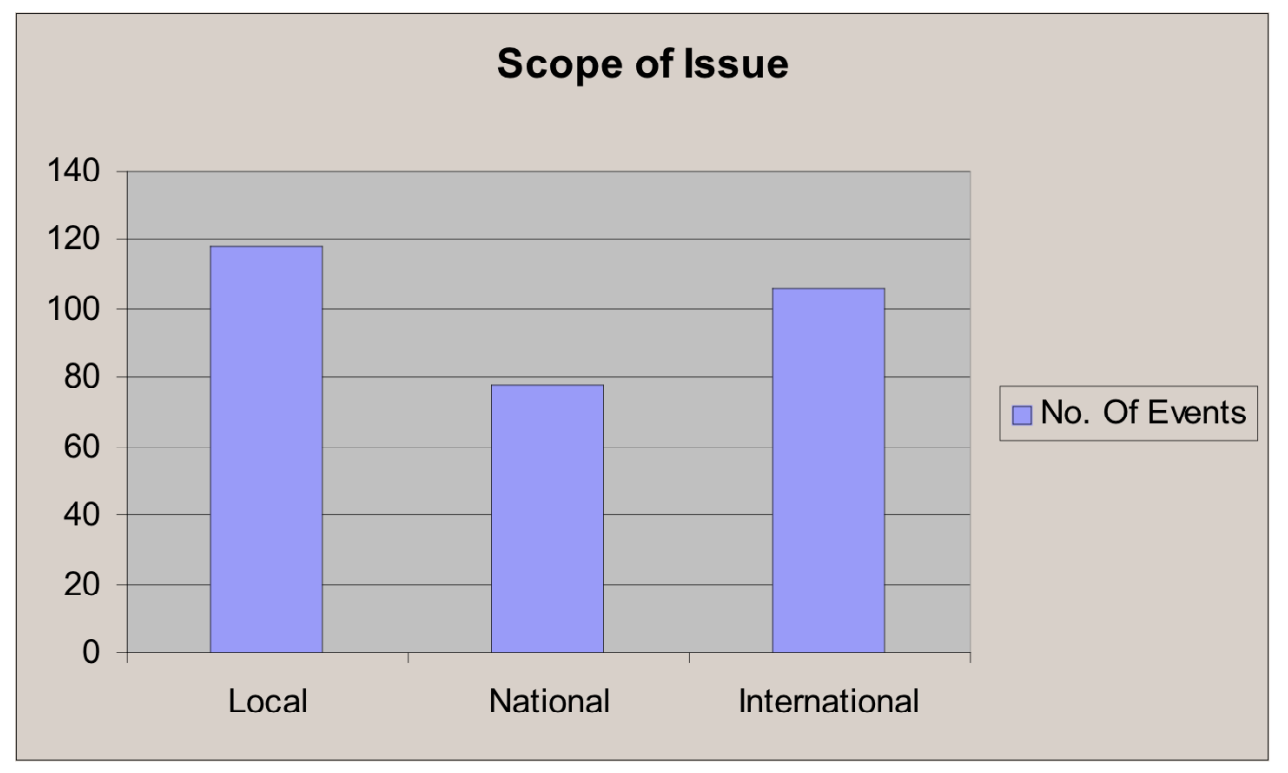

Although there were more events of national and international scope combined, issues of local scope were the single largest category. The majority of protests in Manchester and Oxford were carried out locally and travel to international events was rare in all three areas., The two larger groups were therefore principally local actors, even though it is as national and transnational actors that EDA groups receive most attention. 
The data in table $1^{16}$ provide evidence about the specific claims made in protests that occurred in each of the three localities. ${ }^{17}$ It is clear that the same issues arose in each area, even if in different proportions.

Table 1. Protest Issues in Manchester, Oxford and North Wales 1992-2001, reported in national sources. (Excludes protests which activists from these locations took part in elsewhere; \% for columns.)

\begin{tabular}{|l|c|c|c|}
\hline Claim & $\begin{array}{c}\text { Manchester } \\
(\mathbf{n}=\mathbf{1 1 5})\end{array}$ & $\begin{array}{l}\text { Oxford } \\
\mathbf{( n = 6 2 )}\end{array}$ & $\begin{array}{c}\text { North Wales } \\
\text { (n=22) }\end{array}$ \\
\hline $\begin{array}{l}\text { Landscape, ecosystems, } \\
\text { forestry, resource } \\
\text { extraction }\end{array}$ & 35 & 27 & 45 \\
\hline $\begin{array}{l}\text { Opposing construction, } \\
\text { transport and } \\
\text { communication systems }\end{array}$ & 44 & 39 & 50 \\
\hline Pollution and energy & 11 & 10 & 5 \\
\hline $\begin{array}{l}\text { Democracy, human rights } \\
\text { and anti-military }\end{array}$ & 31 & 29 & 23 \\
\hline Pariah companies & 23 & 21 & 0 \\
\hline Animal rights & 0 & 16 & 36 \\
\hline
\end{tabular}

Column totals are more than $100 \%$ because of the possibility to list two claims per event.

Such differences were not due to differences between the identities of the local groups; rather they were a result of the availability of targets locally. The higher proportion of defence of landscape, forestry and ecosystems in North Wales in comparison to Manchester and Oxford reflects the former's rural environment and specifically opposition to quarries in that area. Yet, even though the number of protests in North Wales was small, the pattern of issues is sufficiently similar to Manchester and Oxford to support the view that EDA groups in each area pursued a similar agenda.

The other two categories of environmental issue - pollution and energy, and opposition to construction - are relatively consistent across the three cases. In North Wales opposition to a new road in Anglesey and a housing scheme in Bangor were especially significant. This was also the only locality with a nuclear power station and so GMEF was the only group that took action against nuclear energy. In Manchester (Fresh Air Now) and Oxford (Oxford is Choking) there were specific EDA-led antipollution campaigns focusing on motor vehicles in the cities. Around a third of total claims relate to opposition to construction, but these protests declined after 1998 as the government's road-building programme was cut and the second runway at Manchester Airport neared completion.

Since EDA groups in the UK developed from an established British tradition of direct action groups which embraced multiple issues it is not surprising that nonenvironmental issues were also significant in their protests. We coded all protests that were reported as involving EDA groups, whether environmental or non- 
environmental. Environmental issues may have been the principal focus of action, but there were also protests by EDA groups on every core issue of the 1970s and 1980s new social movements: feminism, gay and lesbian rights, anti-racism, asylum and immigration, state surveillance, solidarity with the third world, nuclear weapons, opposition to wars, military recruitment and the arms trade, and action in support of the rights of minority groups. Given the commitment of EDA groups to global justice issues it is also hardly surprising to find them active against controversial companies involved in global business. Three stood out as particularly significant targets: Shell, McDonalds and British Aerospace, but banks, other oil companies and supermarkets also featured prominently.

On some larger-scale protests such as those at arms fairs the local EDA groups were part of broader coalitions of anti-arms trade groups and locally, they sometimes worked with other campaigners, for instance in regular protests at the Campsfield asylum-seekers detention centre near Oxford. For the most part, however, they initiated their own protests and campaigns on issues that might be seen as part of 'other' movement domains. The degree of involvement in these by local activist groups varied, for instance, there were some women-only actions, such as one in Manchester to protest against a sexist advert in a chocolate shop in 2000. Since there were no centrally authorised campaigns, any particular protest or campaign whether on environmental or other issues was a project of particular groups of activists within the EDA community, and depended for its success on the ability to mobilise fellow activists through persuasion. There was no sense, therefore in which nonenvironmental campaigns could be defined as marginal or non-essential to the movement. There were also, however, protests that might be thought to be cognate, but which many activists avoided taking part in.

For instance, Oxford alone had a significant number of animal rights-related protests. ${ }^{19}$ A national campaign against Hillgrove farm, near Oxford, where cats were bred for use in vivisection, pulled in a small minority of Oxford EDA activists. However, the animal rights movement is largely separate from the environmental movement and perceived as such by activists. In interviews, EDA activists tended to argue that, although they were sympathetic to some of the arguments of animal rights and animal liberation activists, they thought them too single-issue and most rejected the violence used by a small minority of animal liberation activists. Particularly revealing was an incident, observed by one of the authors, in the Manchester Earth First! office in 2001: an EF! activist found a box with animal rights material and decided to throw it all away 'because that's got nothing to do with Earth First!'. Thus, while animal rights activists were sometimes also involved in EDA groups and part of the same social scene, most EDA activists regarded animal rights as a separate movement.

\section{The Forms of Protest}

The EDA repertoire is based primarily upon confrontational and often illegal forms of direct action. Table 2 is based on data for 1995-2000 (which includes the local sources) as this allows more accurate identification of the differences between actions carried out in the three locations and 'on the road' and shows that all three groups used the same challenging and often-illegal repertoire. Occupations, blockades, protest camps and property damage make up more than half the reported forms of 
action. Moreover, less confrontational forms of action such as leafleting were often used alongside confrontational and disruptive forms during the same event. For instance, office occupations, Reclaim the Streets parties, or disruption of shareholders' meetings usually also involved leafleting of passers-by. ${ }^{20}$

Table 2. Forms of action by location 1995-2000, reported in local and national sources. \% for columns.

\begin{tabular}{|c|c|c|c|c|c|c|c|}
\hline & \multicolumn{3}{|c|}{$\begin{array}{l}\text { Actions in each } \\
\text { location }\end{array}$} & \multicolumn{3}{|c|}{$\begin{array}{l}\text { Actions that activists from } \\
\text { these locations took part in } \\
\text { elsewhere }\end{array}$} & \multirow{2}{*}{$\begin{array}{l}\text { Actions involving } \\
\text { activists from all } \\
\text { three locations } \\
(\mathrm{n}=\mathbf{5 1})\end{array}$} \\
\hline & 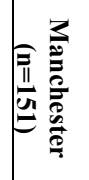 & 䎡是 & 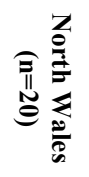 & 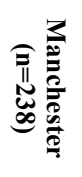 & 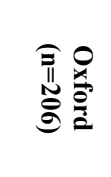 & 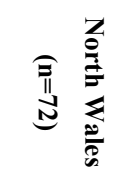 & \\
\hline $\begin{array}{l}\text { Signatures / } \\
\text { leaflets / judicial }\end{array}$ & 17 & 15 & 15 & 13 & 12 & 8 & 4 \\
\hline $\begin{array}{l}\text { Public } \\
\text { demonstrations }\end{array}$ & 23 & 25 & 30 & 23 & 25 & 21 & 18 \\
\hline $\begin{array}{l}\text { Gatherings / } \\
\text { meetings }\end{array}$ & 5 & 5 & 5 & 4 & 4 & 3 & 2 \\
\hline $\begin{array}{l}\text { Occupations / } \\
\text { blockades }\end{array}$ & 33 & 26 & 11 & 35 & 29 & 27 & 33 \\
\hline $\begin{array}{l}\text { Protest camp } \\
\text { events }\end{array}$ & 10 & 4 & 21 & 13 & 11 & 27 & 29 \\
\hline $\begin{array}{l}\text { Property damage / } \\
\text { shoplifting }\end{array}$ & 7 & 14 & 11 & 9 & 13 & 13 & 14 \\
\hline Other & 9 & 12 & 11 & 7 & 9 & 7. & 6 \\
\hline
\end{tabular}

Column totals are more than 100\% because of the possibility to list up to four forms of action per event.

The main difference between the three areas was the lower proportion of occupations and blockades and the higher proportion of demonstrations in North Wales. ${ }^{21}$ GMEF made considerable effort to construct alliances with local NGO and campaign groups from 1999 onwards, playing a central role in organising a rally in Bangor in November against the WTO to coincide with the Seattle meeting, in which Oxfam, Plaid Cymru and Christian Aid took part. They also co-organised a protest at the Welsh Assembly in Cardiff against the Terrorism Act in 2000, at which a supportive message from Rowan Williams, the future Archbishop of Canterbury, was read out. Unlike their larger counterparts based in cities with a stronger radical subculture, GMEF put more effort into maintaining good relations with conventional campaign groups, a necessity if significant numbers were to be attracted to a rally or demonstration. Nevertheless, GMEF were in practice no less militant than the groups in other areas, as evidenced in their willingness to undertake actions involving damage to property and their reluctance to compromise their usual repertoire, even if it undermined relations with their allies. 
This was illustrated when a networking coalition, Cynefyn y Werin (Common Ground), was established in North Wales in January 2000 to bring together groups with a common interest in opposing neo-liberal form of globalization. Many members were NGOs, charities and church groups campaigning for human rights and on aid and development. GMEF was an active member but upset others when its activists prevented Clare Short, the Minister for Overseas Development, from speaking at a public meeting at Bangor University in 2001 by pelting her with a custard pie.

Although all the groups in Cnefin y Werin opposed Short's support for the globalization of trade, other groups were angry that GMEF's action denied them the opportunity to debate the issue in a public meeting, and it took some time for relations to mend.

The evidence shows that EDA is based on confrontational, disruptive and often illegal action, but minimal violence (cf also Rootes, 2003). The vast majority of actions in the property damage category fell into the category of minor damage to property, such as damage to GM crops and 'ethical shoplifting' that involved taking goods such as illegally imported tropical hardwoods from a shop to the local police station and reporting them as stolen goods. While our qualitative research revealed that some covert minor property damage against construction companies or McDonalds restaurants went unreported in EDA newsletters, most of what activists called 'pixieing' was on an opportunistic basis and very small scale. In contrast to parts of US Earth First! in the 1980s (Lee 1995), covert sabotage was not a principal strategy of the EDA networks in the UK (cf Plows et al. 2004). More extensive use of sabotage would probably have led to a more repressive response from the police and courts, as happened to animal liberation activists, and would have threatened the open public mobilisation that was the main strategy of EDA groups.

There were no cases of serious injury or death recorded in the reports we analysed. Force was used by EDA activists in only 14 of the 443 protests we coded in the 19952000 period. Although there were instances of major property damage, such as burning of excavators and diggers and breaking of windows, these were relatively few and mostly took place in the larger and more open rallies, such as the Newbury Reunion Rampage in 1997 or the Carnival Against Capitalism in London in June 1999, with many from outside the EDA networks taking part in the latter. Most EDA activists continued to adhere to the commitment to non-violence, a strong norm in the UK direct action networks since the 1970s.

Given the nature of direct action-type protest, it is un surprising that most protest actions were carried out by small groups of Earth Firsters! Seventy-six percent of events reported involved only one group. Of 192 protests involving these three groups between 1992 and 2001 where numbers were reported, only 63 involved more than 500 people, 35 between 100 and 500, and the rest fewer than 100. Most actions that we observed involved 10-20 activists and it is safe to assume that the 136 events where numbers were not reported involved small groups.

The contentious politics school of social movements tends to see public protest as based on a claim made to authorities (Tarrow 1998; Tilly 2004). In certain respects this is a truism in that as regulators of public space the authorities are likely to be participants in the relations generated by protest but in the case of EDA it would be 
misleading to see their actions as generally claims for the authorities to take action. The most common targets of EDA protest were companies and trade associations rather than the government (just over $51 \%$ of the total for the 1992-2001 period). The state made up the only other significant target (45\%), divided between public institutions (27.6\%) and Government and Ministers (17.3\%). MPs, parties, and trade unions barely figured. This reflected the view of power predominant in EDA discourse, in which business and the national state were viewed as engaged in defending an ecologically unsustainable and socially unjust global capitalist system. Accordingly, it was political and business institutions that needed to be challenged and exposed rather than individuals or other political organisations that needed to be persuaded. For most EDA protestors that we interviewed, this set of targets was reflective of a politics of resistance in which the main appeal was to a potentially mobilisable public rather than to decision-makers. Few had any expectation of being able to leverage concessions from government, gain a seat at the policy-making table, or persuade allies in the political system to take up their cause.

\section{Summary}

This is the first systematic analysis of the protest activity of environmental direct action groups in the UK. Perhaps the most important finding concerns the sheer number of protest actions undertaken. In the six years from 1995-2000, these three local groups were involved in 414 separate recorded protests, which, if representative of other EDA groups in the UK, would mean significant numbers of albeit small scale protests, that were mostly unreported in the local or national media.

EDA groups developed a culture and repertoire of their own that they were able to sustain for more than a decade. They were not part of the mainstream, but were an important part of the local environmental and activist scenes in many of the major cities in the UK. Direct action was the preferred strategic option for these groups, irrespective of the response they gained from those in power or whether they were well-received by the media. Yet being noticed and provoking a response from opponents still mattered. The evidence suggests that the impact of protests against road building, genetic modification, for global justice and later, on climate change, encouraged participants to renew their efforts at various points from 1992 onwards, even if in each instance their impact was also dependent on other political factors and actors. The multiplicity of issues raised in their protests demonstrates that EDA groups were more than simply environmental in their concerns and drew on the frames established by a range of precursor direct action groups in the 1970s and 1980s. The forms of action they used were also part of an inherited repertoire in which confrontation, disruption and illegal action were constrained by a predominant commitment to non-violence.

Protest on local issues constitutes a significant proportion of EDA action. It is precisely this kind of protest that is often missed when we look only at evidence from national sources. All three groups were engaged in similar forms of action on similar issues at national level, but in comparing their local actions some differences were apparent. The group in rural North Wales showed greater orientation towards alliance building because it lacked a critical mass of activists to sustain continuous mobilisation. Bangor also lacked the same range of targets as in the two larger cities, so extra-local actions represented a higher proportion of protests. In this sense the 
historic association of movements with urbanisation (Tilly 2004) still influences even geographically mobile and globally connected activists (Chesters and Welsh 2005). Cities still draw radical activists and provide them with more opportunities to mobilise. However, the North Wales group was just as willing to engage in more militant action even when this undermined relationships with less radical allies. In Manchester and Oxford there was very little joint protest action with other groups. Only in the non-protest campaigns of activists did they work with other groups, for instance in the management of local resource centres.

\section{Sustaining direct action: beyond opportunities and cycles}

EDA protest is resistant to the standard explanations of mobilisation in terms of political opportunities or protest cycles (Tarrow 1998). Political opportunity explanations emphasise the actions of states or other opponents of social movements in providing incentives for protesters to bear the costs of action. It is when new allies become available, opponents seem vulnerable, or the state lowers the cost of repression that action seems most worthwhile (Tarrow 1998: 71). We have already questioned the applicability of this theory to explain the emergence of EDA in the early 1990s (though without rejecting the more general relevance of changes in the political context, Doherty 1999a; Wall 1999) and now also question its use to explain how such groups sustained their protest. Rather than constituting calculated attempts to influence state policy, EDA is based on the aim of developing a resistance culture, in which a way of life is challenged through protest. Activists' anarchistic commitments preclude large-scale organisations, their lifestyle and closed friendship groups inhibit recruitment and strategic alliances, so despite sustained direct action EDA did not become a mass movement. EDA is a foray from an alternative culture in which the aim is to disrupt norms, challenge acquiescence and suggest that alternatives are possible.

It is hard to identify either national or international opportunities or constraints that explain the patterns of EDA protest over these ten years. There were changes such as the shift from road protests to GM crops and to global justice protests but these were in reaction to the imposition of a new grievance in the case of GM or, in the case of global justice, had roots in the international Zapatista solidarity networks in the mid1990s, in which UK EDA activists from groups such as Reclaim The Streets played a part (Olesen 2005, Chesters and Welsh 2005; Wood 2005). Nor was there any significant new repression of EDA protests by the state (difficult against non-violent protesters who had significant levels of public support). ${ }^{22}$

In the three groups that we studied it was not repression, institutionalisation, or polarisation between radicals and reformers that explained the eventual reduction of protest after 2001. Rather, exhaustion (another factor that Tarrow (1998: 147) identifies as a possible explanation of decline) was decisive. But exhaustion requires more detailed explanation, since many activists sustained intense activity for ten years, begging the question why did exhaustion not set in earlier? Exhaustion needs to be considered alongside other factors such as inter-personal tensions within activist communities and the material costs of sustained activism. When activity began to decline in the early 2000s, one reason given for this in interviews was material pressures. Some now had children, and many found it too hard to sustain the lowincome lifestyle of the most committed activists. But, importantly, the EDA network did not disappear altogether and was able to reconstitute itself for national protest 
camp actions on climate change in 2006 and 2007. The solidarity built up between groups of friends over many years of intense political action allowed such networks to re-emerge, even when they seemed to have disappeared.

\section{References}

Chesters, G and Welsh, I (2005) Complexity, Multitudes and Movements: Acting on the Edge of Chaos (London: Routledge).

Doherty, B. 1999a, 'Paving the Way: the Rise of Direct Action and the Changing Character of British Environmentalism', Political Studies, 47 (2): 275-291.

Doherty, B. (1999b) 'Manufactured Vulnerability,' Mobilization 4 (1): 75-89. Doherty, B. (2003) 'Studying Local Activist Communities Over Time: Direct Action in Manchester, Oxford and North Wales 1970-2001,' European Sociological Association, Murcia, September.

Doherty, B. (2002) Ideas and Actions in the Green Movement (London: Routledge).

Doherty, B. Plows, A. and Wall, D. (2003) 'The Preferred Way of Doing Things: the UK Direct Action Movement', Parliamentary Affairs 56 (4): 669-686.

Downs, A. (1972) 'Up and Down with Ecology: the Issue Attention Cycle', The Public Interest, 28: 38-50.

Doyle, T. (1994) 'Direct Action in Environmental Conflict in Australia: A ReExamination of Non-Violent Action', Regional Journal of Social Issues, 28: 1-13. Dunleavy, P., Margetts, H., Smith, T. and Weir, S. (2005) Voices of the People: Popular attitudes to democratic renewal in Britain, (London: Politico's). Epstein, B. (1991) Political Protest and Cultural Revolution: Nonviolent Direct Action in the 1970s and 1980s (Berkeley: University of California Press). Fillieule, O. and Jiménez (2003) 'Appendix A: The Methodology of Protest Event Analysis and the Media Politics of Reporting Environmental Protest Events', in Rootes, C. ed., pp. 258-79.

Haunss, S. and Leach, D.K. (2004) 'Scenes and Social Movements, European Consortium for Political Research, Uppsala, April.

La Rocca (2004) Making a Difference: factors that influence participation in grassroots environmental activism in Australia, unpublished dissertation, Australian School of Environmental Studies, Griffith University, November.

Lee, M. (1995) Earth First! Environmental Apocalypse (New York: Syracuse University Press).

McAdam D. (1983) 'Tactical Innovation and the Pace of Insurgency', American Sociological Review, 48: 735-754.

Olesen, T. (2005) International Zapatismo: The Construction of Solidarity in the Age of Globalization, London: Zed Books.

Polletta, F. (2002) Freedom is an Endless Meeting: Democracy in American Social Movement, Chicago: University of Chicago Press.

Plows, A. (1998) Earth First! in McKay, G. ed. DiY Culture, London: Verso.

Plows, A. Wall, D. and Doherty, B. (2004), 'Covert Repertoires: Ecotage in the UK', (2004) Social Movement Studies, 3 (2): 199-220.

Rootes (2000) 'Environmental Protest in Britain' in Seel et al. (eds.), pp. 25-61.

Rootes, C. (ed.) Environmental Protest in Western Europe (Oxford: Oxford University Press).

Rootes, C. (2003) 'Britain' in Rootes (ed.), pp. 20-58.

Rucht D, Ohlemacher T. (1992) 'Protest event data: collection, uses and perspectives', in M. Diani and R. Eyerman, eds. Studying Collective Action (London: Sage), pp.76-106. 
Seel, B., Paterson, M. and Doherty, B., eds. Direct Action in British

Environmentalism (London: Routledge).

Seel, B. and Plows, A. (2000) 'Coming Live and Direct: strategies of Earth First!', in Seel et al. (eds.), pp. 112-32..

Tarrow, S. (1998) Power in Movement (Cambridge: Cambridge University Press). Tilly,C. (2004) Social Movements, 1768-2004 (Boulder, CO, Paradigm Publishers). Wall, D. (1999) Earth First! and the Anti-Roads Movement (London: Routledge). Wood, L.J. (2005) 'Bridging the Chasms: the Case of People's Global Action', in Bandy, J. and Smith, J., eds Coalitions Across Borders (Oxford: Rowman and Littlefield), pp. 95-117.

\footnotetext{
${ }^{1}$ Correspondence address: Brian Doherty, School of Politics, International Relations and Philosophy, Keele University, ST5 5BG, United Kingdom. Email: b.j.a.doherty@keele.ac.uk

${ }^{2}$ The research for this paper was funded by a grant from the UK Economic and Social Research Council (L215252034) as part of the Democracy and Participation Programme. Acknowledgements are due to Clare Saunders for her work on preparing the data and for comments on drafts from Chris Rootes and Graeme Hayes.

${ }^{3}$ Others in this category included Cambridge, Totnes (Devon), South Somerset, Lancaster, York, Guilford, Exeter, Warwick and Swansea. There is also a third group of major cities that had intermittent EDA groups in the 1990s-2000s: Sheffield, Glasgow, Edinburgh, Birmingham, Bradford and Liverpool.

${ }^{4}$ The influence of previous generations of activists on the EDA generation of the 1990s in Manchester, Oxford and North Wales is examined in Doherty (2003).

${ }^{5}$ One example is the building of tunnels in which protesters could barricade themselves to prevent the destruction of a wood for road building. Although this tactic continued it received much less attention after the first major instances at Fairmile in Devon and Manchester Airport in 1997. By 2006 there was apparently no coverage in the national press of protest camps such as that at Southend using these tactics.

${ }^{6}$ There were 44 attributable to Earth First! but taking into account other named EDA groups takes to the total to 110 . We are grateful to Chris Rootes for providing the organisational frequencies chart from his survey, which allowed us to make this calculation.

${ }^{7}$ To carry out a similar survey in 2007 local activist email lists and Indymedia websites would be the principal available source.

${ }^{8}$ Action Update reports protests by all EDA groups, not only those that use the name Earth First!

${ }^{9}$ In our coding we followed the definition of an event given by Fillieule and Jiménez (2003: 273-4).

This meant that even large scale protests such as the Carnival Against Capitalism on June $18^{\text {th }} 1999$, which included tens of separate actions at different locations, were recorded as a single event on the basis that the protests were carried out by a network who had worked together to plan the protest, and took place close to each other in time (within a few hours) and space (within the City of London) .

${ }^{10}$ We did not code a protest camp as a form of action in itself but we did code specific events separately when they were reported such as occupying a site and building defences, or an eviction (see appendix). Like Rootes (2003: 55, f.n. 22) we coded only specific reported events even when a protest camp lasted for months.

${ }^{11}$ After 1998 there were far fewer Oxford EDA actions reported to Action Update, but this seems to be an anomaly since the local Oxford newsletter reported a continuing high level of protest activity in 1999 and 2000 (see Figure 2). It seems that after 1998 no one in Oxford was passing on reports to the EFAU in the ways that they had done in previous years. The reason for this was that the old Earth First! group had broken up and while EDA action continued, and was mostly carried out by the same people who had been in Oxford Earth First!, the local EDA scene lacked the umbrella identity that EF! had provided. This is the main example of the limitations of EDA sources that we encountered.

${ }^{12}$ When activists from each area took part in a particular protest action at Newbury that single event was counted separately for each area.

${ }^{13}$ The survey of environmental protest in The Guardian showed that 1995 was the peak year for environmental and animal welfare protest in the 1988-97 period, but 1996 had a higher level of protest than 1995 on transport issues (Rootes 2003: 31) which seems to fit the pattern from EDA sources.
} 
${ }^{14}$ All interviewee names are pseudonyms. We interviewed 59 activists in total across the three locations between 2000 and 2002. For articles which make more use of this material see Doherty 2003; Doherty et al 2003and Plows et al 2004.

${ }^{15}$ A single event was only classified in one category. For instance, in Manchester activists took part in protests against the closure of a school and the destruction of a pond in the part of the city where most activists lived, events that were clearly local in scope. Events of national scope included demonstrations organised to disrupt the Manchester visit of the Home Secretary, Jack Straw, in protest against national government legislation. An example of an event in Manchester of international scope was a blockade to disrupt an international conference of government ministers and business leaders to discuss sustainable development in September 1993.

${ }^{16}$ We have not presented separate data based on the local sources here mainly for reasons of space but also because there were no major differences between the two sets of data. Overall the main effect of including local sources was that the numbers of non-environmental claims were increased slightly, by around $10-15 \%$ relative to the environmental claims. This is not surprising, since protests on issues such as the Kosovo and Afghanistan wars, legislation such as the Terrorism Act 2000, or seeking to prevent deportation of asylum seekers, often involved the EDA groups in local coalitions, whose actions were more likely to be reported in a local newsletter.

${ }^{17}$ The figures exclude protests in other areas in which groups from the three areas took part because doing so allows for a clearer analysis of the effect of local context on the type of issues raised in protests.

${ }^{18}$ This figure excludes those pariah companies targeted for their involvement with military production (eg British Aerospace) when not mentioned in tandem with a more general anti-military claim.

${ }^{19}$ Comparison with the local newsletter and participant observation data for 1995-2001 showed no animal rights EDA activity in North Wales, a slightly smaller proportion in Oxford and a small amount of activity by the Manchester Animal Protection (MAP) and hunt saboteurs groups ( $4 \%$ of claims).

${ }^{20}$ The low proportion of leafleting reported in national events involving groups from all three locations was very likely due to lack of space in reports of major protests.

${ }^{21}$ In Manchester there was a high proportion of occupations and blockades because of the central role played by Manchester activists in campaigns against the loans made by Lloyds and Midland to oppressive countries in the global South and a campaign against arms exports by British Aerospace, which centred upon occupying workplaces, as well as the higher number of offices of other pariah companies in Manchester.

${ }^{22}$ Surveys of opinion on protests in 2000 showed significant support for some EDA protests including destruction of GM crops and the anti-capitalist street demonstrations in London, (Dunleavy et al. 2005: 150-3). 